\title{
Effects of Breed on Reproductive Efficiency of Two Most Popular Snails [Archachatina marginata (S) and Achatina achatina (L)] in Nigeria
}

\author{
Okon B. ${ }^{1}$, Ibom L. A. ${ }^{1}$, Williams M. E. ${ }^{2}$, \& Ekong N. B. ${ }^{1}$ \\ ${ }^{1}$ Department of Animal Science, University of Calabar, Calabar, Nigeria \\ ${ }^{2}$ AKS College of Agriculture, Obio Akpa, Uruk - Anam, L. G. A., Nigeria \\ Correspondence: Okon B., Department of Animal Science, University of Calabar, Calabar, Nigeria. E-mail: \\ blessedbassey4destiny@yahoo.com
}

Received: July 27, 2011 Accepted: August 8, 2011 Online Published: July 27, 2012

doi:10.5539/jas.v4n8p236 URL: http://dx.doi.org/10.5539/jas.v4n8p236

\begin{abstract}
The effects of breed on the reproductive efficiency of the two most popular snail breeds [Archachatina marginata (S) and Achatina achatina (L)] in Nigeria were evaluated. Sixty snails each of the Archachatina marginata and the Achatina achatina breeds consisting of 30 black-skinned and 30 white-skinned ectotypes each of A. marginata and A. achatina were used. The snails were randomized into three mating groups; black-skinned $\mathrm{x}$ black-skinned (BS X BS), white-skinned $\mathrm{x}$ white-skinned (WS X WS) and black-skinned x white-skinned crossbred (BS X WS) and replicated five times in the randomized complete block design. Results of the study on mean egg traits revealed a highly significant $(\mathrm{P}<0.01)$ mean egg weight and mean egg length at lay between the black-skinned purebred and the black-skinned $\mathrm{x}$ white-skinned crossbred. The mean egg width also indicated highly significant $(\mathrm{P}<0.001)$ differences between the black-skinned purebreds of $A$. marginata and A. achatina. The variations in mean egg traits between the two breeds and the crosses of their ectotypes in this study may indicate variation in genetic composition of the snails. Results of hatchling traits evaluated showed that there also was a highly significant difference $(\mathrm{P}<0.001)$ in mean hatchling weights between the black-skinned purebreds of $A$. marginata and $A$. achatina. The hatchlings mean shell length results also showed significant differences $(\mathrm{P}<0.05)$ between the black-skinned purebreds and the crossbreds mating groups in the two breeds. The percent variability results indicated that high and low percent egg weight variability existed between the black-skinned purebred and the crossbred mating groups of the $A$. marginata and $A$. achatina at lay. There also was high and low percent variability for egg weight at hatch for the black-skinned purebred and the black- and white- skinned crossbred mating groups. The variability observed among the traits of hatchlings was due to genetic factors and could mean that their improvement will not be markedly influenced by the environment. The results of correlation among traits revealed positive and highly significant phenotypic correlation $\left(r_{p}\right)$ within egg and hatchling traits for the two snail breeds studied. The correlation could suggest that there are direct relationships between the traits, and that selection for one trait will lead to improvement in the other trait. It is recommended that intensive domestication and massive production of $A$. marginata be embarked upon since it appears to have higher potentials to meet the animal protein supply of the populace than A. achatina. This is because of its larger size.
\end{abstract}

Keywords: economic traits, ectotypes, genetic factors, micro-livestock, tropics

\section{Introduction}

Nigeria is known to be richly endowed with different species of snails, varying in size, colour, adaptability and performance (Odunaiya, 1995; Amusan \& Omidiji, 1998; Ibom, 2009). These include Archachatina marginata (plates 1, 2, 3, 4 and 5), Achatina achatina (plate 6), Achatina fulica (plate 7), Limicolaria species (plates 8 and 9) and Thapsia species (Odunaiya, 1995). The African giant land snail (Archachatina marginata) is the largest known snail in Africa (Omole, 1998; Olawoyin \& Ogogo, 2006) and dwells naturally in the forest litters of the Tropical rainforest zone of Nigeria (Imevbore, 1990; Adedire et al., 1999). 


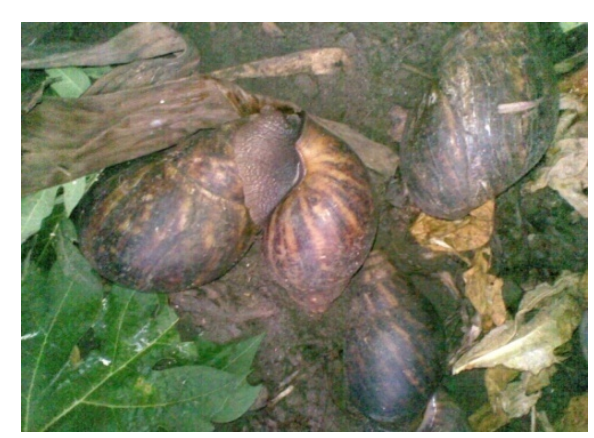

Black-skinned A. marginata

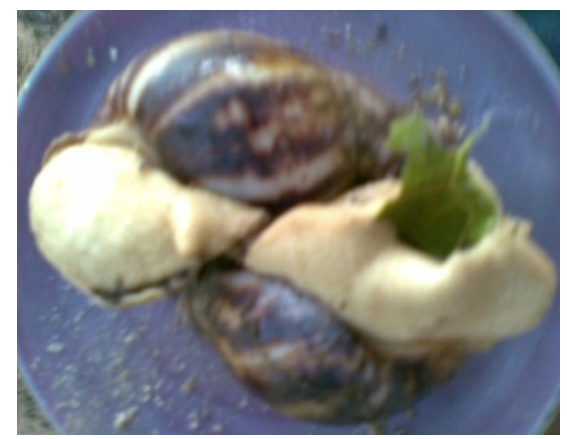

White-skinned A. marginata

Plate 1. Strains of Archachatina marginata

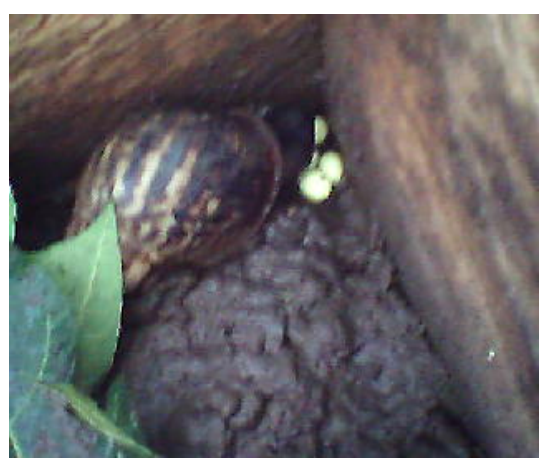

Plate 2. Black-skinned A. marginata depositing eggs in the soil

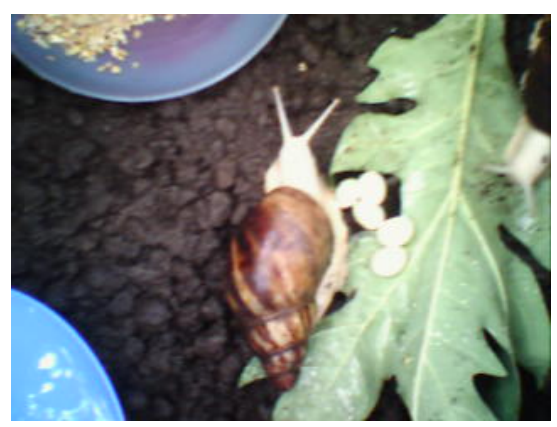

Plate 4. White-skinned A. marginata dropping eggs on pawpaw leaf

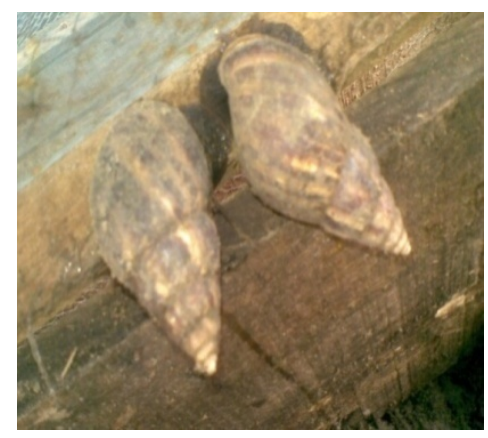

Plate 6. Achatina achatina

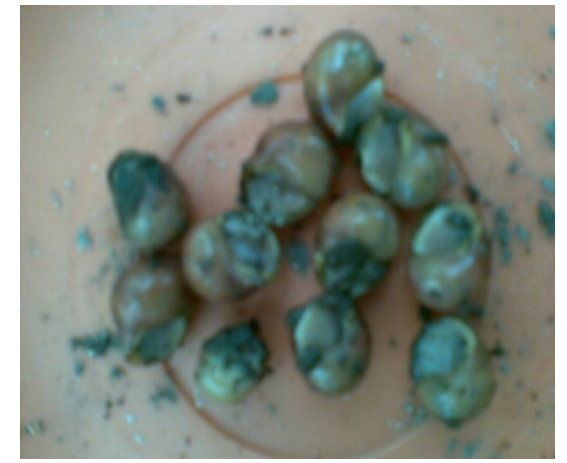

Plate 3. Black-skinned snail hatchlings



Plate 5. White-skinned snail hatchlings

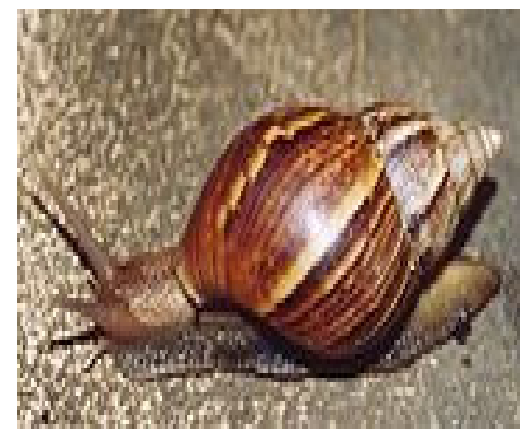

Plate 7. Achatina fulica 


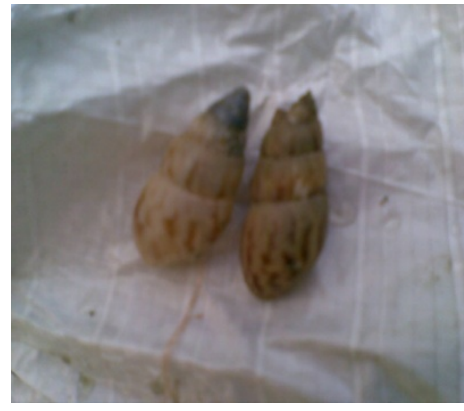

Plate 8. Limicolaria mortensis

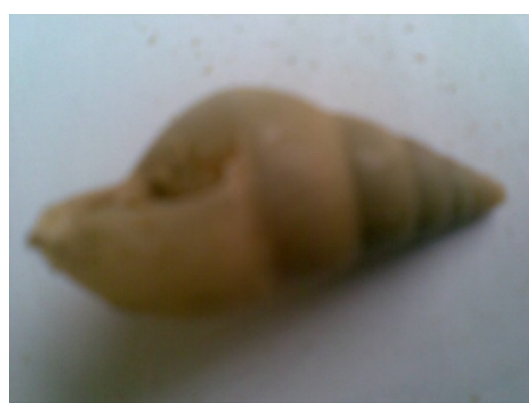

Plate 9. Limicolaria aurora

\section{Limicolaria Species}

Snails have high rate of productivity or fecundity. Though they are hermaphrodites, they practice sexual reproduction (Akinnusi, 2004). Snails are selective in their mating partners and sometimes uninterested in mating with other snails of the same species originating from a considerable distance away (Omole \& Kehinde, 2005). Reports on mating and crossbreeding between the black-skinned and white-skinned snails, reproductive performance of the albino snails and evaluation of egg quality parameters of black- and white- skinned snails had been reported by Ibom (2009) and Okon et al. (2009a, b) and Okon et al. (2011). These authors reported the possibility of mating between the black- and white- skinned ectotypes of snails. According to Omole et al. (2007) and Ibom (2009), snails lay between 4-128 and 1-13 eggs respectively within 2-3 minutes which are hatched within 28-32 days. Omole et al. (2007) also noted that with ten breeding A. achatina, about 400,000 snails can be produced at the end of the first year of reproduction. Similarly, Akinnusi (2004) noted that a snail farm started with 50 snails has the capacity of producing about 5000 snails in 3 months.

Snails are minor forest products that are being domesticated as micro-livestock, and used as animal protein source to complement the conventional and regular sources of animal protein supply in Nigeria. They are cheaper and safer to handle and requires low capital outlay to start. According to Ajayi et al (1978), Awesu (1980), Adeyeye (1996), Akinnusi (2002) and Ejidike (2002), snail meat is high in protein, iron, calcium and phosphorus, but low in sodium, fat and cholesterol, and contains almost all the amino acids needed by man. Adeyeye (1996) further stated that the African giant snail (A. marginata and A. achatina) are considered as a delicacy in Nigeria and they command high demand in the market.

There is need to establish ideal breeds of snail for effective and proper cropping since variability exist in any given snail population. Selection efficiency depends on the variability in a population and the extent to which such variability is heritable (Okon, 2008). Therefore, the logical way to start any breeding programme is to survey the variations, especially in phenotypic traits (body size, shell shape, in terms of length, width, whorl number and type, aperture length and width) present in the breeding material (snail for this study).

Following the high productivity of snails, there is need to assess the variations on the egg and hatchling traits of the two most popular snail species, A. marginata and A. achatina and their crosses in Nigeria. This will help in selection and concentration of rearing efforts on the breed with more promising reproductive characteristics.

\section{Materials and Methods}

\subsection{Study Area and Snail Species}

The study was conducted at the Botanical garden of the University of Calabar, Calabar, Nigeria. The description of the area and climate were as prescribed in Okon et al (2009a, b). One hundred and twenty adult breeder snails, sixty each of Archachatina marginata and Achatina achatina breeds were used. These consisted of 30 snails each of the black- and white- skinned ectotypes of $A$. marginata and 30 snails each of the black- and whiteskinned ectotypes of A. achatina. The weight of the snails ranged from 55.4-59.0 $\mathrm{g}$ and 50.3-58.6 $\mathrm{g}$ for the two breeds (Archachatina marginata and Achatina achatina respectively). The snails were selected based on active appearance and no injury on the foot and/or shell from a base population. The selected snails were grouped into three treatments (mating groups); viz: black-skinned x black-skinned (BS X BS), white-skinned x white-skinned (WS X WS) and black-skinned $\mathrm{x}$ white-skinned crossbred (BS X WS) and replicated five times in the randomized complete block design. 


\subsection{Management and Breeding Pattern}

The management of snails and breeding (mating) pattern were done as prescribed by Ibom (2009) and Okon et al $(2009 \mathrm{a}, \mathrm{b})$. That is, the snails were managed in wooden cage compartments kept outside under trees shade. Each cell of the cage compartments measured $40 \mathrm{~cm}$ (length) x $40 \mathrm{~cm}$ (width) x $30 \mathrm{~cm}$ (height) and housed two snails (two black-skinned ectotype for the BS X BS mating group, two white-skinned ectotype for the WS X WS mating group and one black-skinned and one white-skinned ectotypes for the BS X WS mating group). Allowing two snails (ectotypes) per cell was to be sure that egg(s) obtained there from was a result of the mating between these two. The breeding system used in this study was the natural mating at a ratio of 1:1. The snails were fed on a mixed feeding regime of forage (pawpaw leaves) supplemented with compounded diet. The diet contain $24 \%$ $\mathrm{CP}, 2650 \% \mathrm{ME}$ and $15 \% \mathrm{Ca}$ with the following ingredients; maize, soybean meal, fish meal, bone meal, oyster shell and vit./min. premix. Feed and water in shallow troughs were given ad libitum throughout the study period (120 days).

\subsection{Data Collection and Analysis}

Data collected on egg traits included egg weight, egg length and egg width, while those for the hatchling traits were body weight, shell length and shell width for both breeds and their crosses. Data were always taken for two weeks $(0,1$ and 2$)$ for the egg traits, while there were four weeks $(0,1,2,3$ and 4$)$ readings for the hatchling traits. Week 0 for the egg traits represents data at lay or initial, while week 2 represents the last data taken before hatch. Similarly, week 0 for the hatchling traits data represents readings at hatch, while week 4 represents the last data taken on the hatchlings. Weight was measured using a Scout ${ }^{\mathrm{TM}}$ Pro electronic scale with $0.01 \mathrm{~g}$ sensitivity, while measurements of the length and width were done using Vernier caliper. These data were subjected to analysis of variance using Procmean procedure of SAS (1995) package. T-test statistical tool as modified by Madukwe (2004) was used to compare means of measured parameters between the breeds. Phenotypic correlations among egg and hatchling traits were also compared according to methods outlined by Ibe (1998). This was done to determine whether same genes affected two or more traits, and whether such relationship was high or low, positive or negative or neutral.

\section{Results and Discussion}

\subsection{Egg and Hatchling Traits}

The results of mean egg traits are presented in Table 1 . They revealed that at lay, the eggs of $A$. marginata are larger and heavier than those of A. achatina. The egg weights at lay were $1.83 \mathrm{~g}$ and $0.73 \mathrm{~g}, 1.08 \mathrm{~g}$ and $1.08 \mathrm{~g}$ and $1.13 \mathrm{~g}$ and $0.77 \mathrm{~g}$ for the black-skinned purebred, white-skinned purebred and the black-skinned $\mathrm{x}$ whiteskinned crossbred ectotypes of $A$. marginata and A. achatina respectively. These differences in mean egg weights between the two snail breeds and their crosses were highly significant $(\mathrm{P}<0.01)$ only between the blackskinned purebred and the black-skinned $\mathrm{x}$ white-skinned crossbred. The mean egg weight values obtained in this study for the black-skinned and white-skinned purebred ectotypes were quite similar to the mean values of 1.80 $\mathrm{g}$ and $1.05 \mathrm{~g}$ obtained by Ibom et al. (2008) for the black-skinned and white-skinned purebreds respectively, but lower than the mean values of $2.7 \mathrm{~g}(2.6-2.9 \mathrm{~g})$ and $2.4 \mathrm{~g}(2.3-2.5 \mathrm{~g})$ recorded by Okon et al. $(2009 \mathrm{~b})$ for the black-skinned and white-skinned purebreds of $A$. marginata in the same study area. On the other hand, Amubode (1994) obtained quite higher mean egg weights of $3.5 \mathrm{~g}$ and $3.0 \mathrm{~g}$ for A. marginata and A. achatina respectively.

Table 1. \pm SEM of egg traits of Archachatina marginata and Achatina achatina

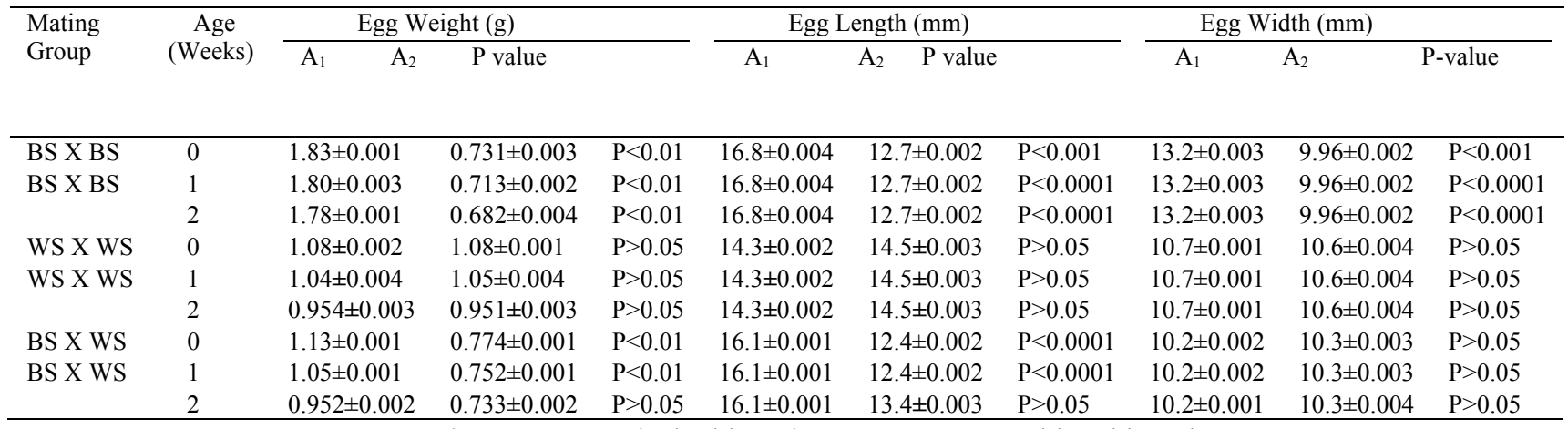

$\mathrm{A}_{1}=$ A. marginata, $\mathrm{A}_{2}=$ A. achatina, $\mathrm{BS}=$ Black-skinned ectotype, $\mathrm{WS}=$ White-skinned ectotype. 
Variations in mean egg weights between the two breeds and the crosses of their ectotypes in this study may indicate variation in genetic composition of the snails, especially as the black-skinned A. marginata purebred are naturally bigger in size than the black-skinned $A$. achatina purebred. The results obtained further revealed that mean egg weight decreased with age as the eggs approached hatching date (Table 1). Ibom (2009) and Okon et al. (2009a) stated that decrease in egg weight with age are due to changes in the egg liquid mass to baby snail during the embryonic development as well as the baby snail feeding on the liquid mass, thus making the egg lighter.

The mean egg length (Table 1) obtained for the black-skinned purebreds and the black-skinned $\mathrm{x}$ white-skinned crossbreds were significantly different $(\mathrm{P}<0.001)$. Besides, mean egg length of $A$. marginata was longer than that of $A$. achatina for the black-skinned purebreds and the crossbreds but the reverse is true for the white-skinned (albino) purebred. At lay, the mean egg length obtained were $16.8 \mathrm{~mm}$ and $12.7 \mathrm{~mm}$ for black-skinned purebreds of $A$. marginata and $A$. achatina respectively. These values were higher than the mean egg length values of 1.61 $\mathrm{mm}$ and $1.43 \mathrm{~mm}$ reported by Ibom et al. (2008), but quite close to earlier range values of 12.8-15.4 $\mathrm{mm}$ reported by Okon et al. (2009a) for albino (white-skinned) A. marginata. The results further confirmed earlier research findings by Ibom (2009) and Okon et al. (2009a) that snails' egg length do not change during incubation period through hatching (Table 1). However, there was no significant difference $(\mathrm{P}>0.05)$ in mean egg length between the white-skinned purebreds of $A$. marginata and $A$. achatina, confirming the negative percent variability value of $-1.68 \%$ recorded for egg length (Table 2 ).

Table 2. Percent variability among egg traits of A. marginata and A. achatina

\begin{tabular}{lrrrr}
\hline Mating group & Age (Weeks) & \multicolumn{3}{c}{ Percent Variability } \\
\cline { 3 - 5 } & & Egg Weight & Egg Length & Egg Width \\
\hline BS X BS & 0 & 60.1 & 19.5 & 24.6 \\
& 1 & 60.6 & 19.5 & 24.6 \\
WS X WS & 2 & 61.8 & 19.5 & 24.6 \\
& 0 & 0.00132 & -1.68 & 1.12 \\
BS X WS & 1 & 0.000962 & -1.68 & 1.12 \\
& 2 & 0.00312 & -1.68 & 1.12 \\
& 1 & 31.9 & 22.5 & -1.18 \\
& 2 & 28.6 & 22.5 & -1.18 \\
& 1 & 23.2 & 22.5 & -1.18 \\
\hline
\end{tabular}

$\mathrm{BS}=$ Black-skinned ectotype, WS = White-skinned ectotype.

The mean egg width results obtained were $13.2 \mathrm{~mm}$ and $9.96 \mathrm{~mm}, 10.7 \mathrm{~mm}$ and $10.6 \mathrm{~mm}$ and $10.2 \mathrm{~mm}$ and 10.3 $\mathrm{mm}$ for black-skinned $\mathrm{x}$ black-skinned, white-skinned $\mathrm{x}$ white-skinned and black-skinned $\mathrm{x}$ white-skinned mating groups. These values for the white-skinned purebred and the crossbred are quite similar to the earlier range reports of 10.2-11.5 mm obtained for white-skinned A. marginata by Okon et al. (2009a). The blackskinned purebred of $A$. marginata recorded quite higher mean egg width value of $13.2 \mathrm{~mm}$; though this value was within the range of 9.3-19.3 mm reported by Plummer (1975). The mean egg width results of this study indicated that highly significant $(\mathrm{P}<0.001)$ differences existed between the black-skinned purebreds of $A$. marginata and $A$. achatina, while the differences between the white-skinned (albino) purebreds and the crossbreds in the two breeds were non-significant $(\mathrm{P}>0.05)$. The differences in mean egg width could be traced to variability in size between the two breeds, as the shell of $A$. marginata is wider and bigger than that of $A$. achatina. The constancy in the mean egg length and mean egg width recorded in this study for the two breeds showed that there were no changes in the length and width of eggs during incubation (Table 1).

The mean values of hatchling traits for the two breeds of snail studied are presented in Table 3 . The results revealed that $A$. marginata hatched heavier and bigger snailets or baby snails than $A$. achatina. Consequently, the snailets of $A$. marginata grow faster and heavier than those of A. achatina at maturity, thereby having higher potentials to meet animal protein supply than A. achatina (Odunaiya and Akinyemi 2008). There was higher significant difference $(\mathrm{P}<0.01)$ in mean hatchling weights between the black-skinned purebreds of $A$. marginata and $A$. achatina; but no significant difference $(\mathrm{P}>0.05)$ effect in mean hatchling weights between the crossbreds and the white-skinned purebreds of $A$. marginata and A. achatina. These results were however within the mean hatchling weight range of $0.66-0.93 \mathrm{~g}$ reported by Okon et al. (2009a) for the white-skinned purebred $A$. marginata, with exception of the $1.14 \mathrm{~g}$ mean hatchling body weight recorded for the black-skinned purebred. The mean weight of hatchlings increased with age for the three mating groups of the two breeds (Table 3 ). 
Table 3. \pm S.EM. of hatchling traits of Archachatina marginata and Achatina achatina

\begin{tabular}{|c|c|c|c|c|c|c|c|c|c|c|}
\hline \multirow{2}{*}{$\begin{array}{l}\text { Mating } \\
\text { group }\end{array}$} & \multirow{2}{*}{$\begin{array}{c}\text { Age } \\
\text { (Weeks) }\end{array}$} & \multicolumn{3}{|c|}{ Body Weight of Hatchlings(g) } & \multicolumn{3}{|c|}{ Shell Length of Hatchlings(mm) } & \multicolumn{3}{|c|}{ Sell Width of Hatchlings $(\mathrm{mm})$} \\
\hline & & $\mathrm{A}_{2}$ & P-value & & $\overline{A_{1}}$ & P-valu & & $\overline{\mathrm{A}_{1}}$ & $\overline{A_{2}}$ & lue \\
\hline \multirow[t]{5}{*}{ BS X BS } & 0 & $1.14 \pm 0.003$ & $0.541 \pm 0.001$ & $\mathrm{P}<0.01$ & $14.3 \pm 0.004$ & $12.3 \pm 0.002$ & $\mathrm{P}<0.05$ & $11.8 \pm 0.003$ & $9.72 \pm 0.002$ & $\mathrm{P}<0.05$ \\
\hline & 1 & $1.21 \pm 0.003$ & $0.604 \pm 0.002$ & $\mathrm{P}<0.01$ & $14.6 \pm 0.004$ & $12.7 \pm 0.002$ & $\mathrm{P}<0.05$ & $12.5 \pm 0.003$ & $10.2 \pm 0.002$ & $\mathrm{P}<0.05$ \\
\hline & 2 & $1.30 \pm 0.001$ & $0.673 \pm 0.004$ & $\mathrm{P}<0.01$ & $15.2 \pm 0.004$ & $13.2 \pm 0.002$ & $\mathrm{P}<0.05$ & $13.1 \pm 0.003$ & $10.7 \pm 0.002$ & $\mathrm{P}<0.05$ \\
\hline & 3 & $1.38 \pm 0.002$ & $0.784 \pm 0.001$ & $\mathrm{P}<0.01$ & $15.8 \pm 0.002$ & $13.8 \pm 0.003$ & $\mathrm{P}<0.05$ & $13.6 \pm 0.001$ & $11.3 \pm 0.004$ & $\mathrm{P}>0.05$ \\
\hline & 4 & $1.46 \pm 0.004$ & $0.862 \pm 0.004$ & $\mathrm{P}<0.01$ & $16.5 \pm 0.002$ & $14.2 \pm 0.003$ & $\mathrm{P}<0.05$ & $14.2 \pm 0.001$ & $11.1 \pm 0.004$ & $\mathrm{P}<0.05$ \\
\hline \multirow[t]{5}{*}{ WS X WS } & 0 & $0.771 \pm 0.003$ & $0.712 \pm 0.003$ & $\mathrm{P}>0.05$ & $14.0 \pm 0.002$ & $13.8 \pm 0.003$ & $\mathrm{P}>0.05$ & $10.3 \pm 0.001$ & $10.1 \pm 0.004$ & $\mathrm{P}>0.05$ \\
\hline & 1 & $0.874 \pm 0.001$ & $0.871 \pm 0.001$ & $\mathrm{P}>0.05$ & $14.1 \pm 0.001$ & $15.2 \pm 0.002$ & $\mathrm{P}>0.05$ & $11.3 \pm 0.002$ & $11.1 \pm 0.003$ & $\mathrm{P}>0.05$ \\
\hline & 2 & $0.972 \pm 0.001$ & $1.00 \pm 0.001$ & $\mathrm{P}>0.05$ & $15.6 \pm 0.001$ & $15.9 \pm 0.002$ & $\mathrm{P}>0.05$ & $12.0 \pm 0.002$ & $11.7 \pm 0.003$ & $\mathrm{P}>0.05$ \\
\hline & 3 & $1.09 \pm 0.002$ & $1.11 \pm 0.002$ & $\mathrm{P}>0.05$ & $16.6 \pm 0.001$ & $16.5 \pm 0.003$ & $\mathrm{P}>0.05$ & $12.7 \pm 0.001$ & $12.4 \pm 0.004$ & $\mathrm{P}>0.05$ \\
\hline & 4 & $1.23 \pm 0.003$ & $1.20 \pm 0.004$ & $\mathrm{P}>0.05$ & $17.5 \pm 0.003$ & $17.1 \pm 0.004$ & $\mathrm{P}>0.05$ & $13.5 \pm 0.004$ & $13.0 \pm 0.004$ & $\mathrm{P}>0.05$ \\
\hline \multirow[t]{5}{*}{ BS X WS } & 0 & $0.733 \pm 0.001$ & $0.703 \pm 0.001$ & $\mathrm{P}<0.05$ & $14.9 \pm 0.002$ & $12.0 \pm 0.001$ & $\mathrm{P}<0.01$ & $9.96 \pm 0.001$ & $10.1 \pm 0.001$ & $\mathrm{P}>0.05$ \\
\hline & 1 & $0.951 \pm 0.002$ & $0.802 \pm 0.001$ & $\mathrm{P}<0.05$ & $16.2 \pm 0.003$ & $12.7 \pm 0.002$ & $\mathrm{P}<0.01$ & $11.0 \pm 0.001$ & $10.8 \pm 0.001$ & $\mathrm{P}>0.05$ \\
\hline & 2 & $1.12 \pm 0.003$ & $0.884 \pm 0.002$ & $\mathrm{P}>0.05$ & $17.2 \pm 0.003$ & $13.4 \pm 0.001$ & $\mathrm{P}<0.01$ & $12.1 \pm 0.002$ & $11.2 \pm 0.002$ & $\mathrm{P}>0.05$ \\
\hline & 3 & $1.28 \pm 0.004$ & $1.00 \pm 0.002$ & $\mathrm{P}>0.05$ & $18.1 \pm 0.004$ & $14.1 \pm 0.002$ & $\mathrm{P}<0.01$ & $12.7 \pm 0.003$ & $11.7 \pm 0.002$ & $\mathrm{P}>0.05$ \\
\hline & 4 & $1.46 \pm 0.004$ & $1.07 \pm 0.003$ & $\mathrm{P}>0.05$ & $18.9 \pm 0.004$ & $14.7 \pm 0.002$ & $\mathrm{P}<0.01$ & $13.5 \pm 0.004$ & $12.1 \pm 0.003$ & $\mathrm{P}>0.05$ \\
\hline
\end{tabular}

$\mathrm{A}_{1}=$ A. marginata, $\mathrm{A}_{2}=$ A. achatina, $\mathrm{BS}=$ Black-skinned ectotype, $\mathrm{WS}=$ White-skinned ectotype.

The mean shell length of hatchlings obtained for A. marginata and A. achatina were $14.3 \mathrm{~mm}$ and $12.3 \mathrm{~mm}, 14.0$ and $13.8 \mathrm{~mm}$ and $14.9 \mathrm{~mm}$ and $12.0 \mathrm{~mm}$ (Table 3) at hatch for black-skinned $\mathrm{x}$ black-skinned, white-skinned $\mathrm{x}$ white-skinned and black-skinned $\mathrm{x}$ white-skinned mating groups respectively. At four weeks of age, the shell length of hatchlings had increased to $16.5 \mathrm{~mm}$ and $14.2 \mathrm{~mm}, 17.5 \mathrm{~mm}$ and $17.1 \mathrm{~mm}$ and $18.9 \mathrm{~mm}$ and $14.7 \mathrm{~mm}$ for the black-skinned x black-skinned, white-skinned $\mathrm{x}$ white-skinned and black-skinned $\mathrm{x}$ white-skinned mating groups of the two breeds. These values were quite lower than the mean values of $20.5 \mathrm{~mm}$ and $17.5 \mathrm{~mm}$ reported by Amubode (1994) for A. marginata and A. achatina respectively. The differences in shell length could be attributed to variations in the breeds of snails used, age of the snails at mating and incubation condition, size of snails, as well as other environmental factors during incubation of eggs and rearing of snailets or juvenile snails. There were significant differences $(\mathrm{P}<0.05)$ in mean shell length of hatchlings between the black-skinned purebreds (BS X BS) and the crossbreds (BS X WS) mating groups in the two breeds; while the white-skinned purebred (WS X WS) mating group did not show any significant difference $(\mathrm{P}>0.05)$ in mean shell length between the two breeds.

Mean shell width of hatchlings obtained for A. marginata and A. achatina at hatch were $11.8 \mathrm{~mm}$ and $9.72 \mathrm{~mm}$, $10.3 \mathrm{~mm}$ and $10.1 \mathrm{~mm}$ and $10.0 \mathrm{~mm}$ and $10.1 \mathrm{~mm}$ for black-skinned $\mathrm{x}$ black-skinned, white-skinned x whiteskinned and black-skinned $\mathrm{x}$ white-skinned mating groups respectively. These values were quite lower than the $15.7 \mathrm{~mm}$ and $14.1 \mathrm{~mm}$ values recorded by Amubode (1994) for A. marginata and A. achatina respectively. At four weeks of age, there was significant increment in shell width of hatchlings to $14.2 \mathrm{~mm}$ and $11.7 \mathrm{~mm}, 13.5$ $\mathrm{mm}$ and $13.0 \mathrm{~mm}$ and $13.5 \mathrm{~mm}$ and $12.1 \mathrm{~mm}$ for the black-skinned $\mathrm{x}$ black-skinned, white-skinned $\mathrm{x}$ whiteskinned and black-skinned $\mathrm{x}$ white-skinned mating groups respectively, confirming Odunaiya and Akinyemi (2008) view that shell width of A. marginata is wider at the posterior compared to others (A. achatina).

\subsection{Percent Variability in Egg and Hatchling Traits}

Percent variability obtained for egg traits of the two snail breeds are presented on Table 2 . There was a high and low percent variability of $60.1 \%$ and $31.8 \%$ at lay for the black-skinned purebred (BS X BS) and black- and white- skinned crossbred mating groups of the $A$. marginata and A. achatina respectively, while there was zero percent variability $(0.00132 \%)$ of egg weight at lay for the white-skinned purebred mating groups of the two breeds. Similarly, there was a high and low percent variability of $61.8 \%$ and $23.2 \%$ at hatch for egg weight of the black-skinned purebred and the black- and white- skinned crossbred mating groups. Again, there was also zero percent variability $(0.00312 \%)$ of egg weight at hatch for the white-skinned purebred mating groups of the two breeds. These results further confirmed the findings that $A$. marginata eggs are bigger and heavier in size than those of A. achatina, and that there is little or no differences in egg size of A. marginata and A. achatina. From the foregoing, it could be inferred that the variability observed among the traits was due to genetic factors. This means that their improvement will not be markedly influenced by the environment. 
On egg length, the black- and white- skinned crossbred mating groups had the highest percent variability, though a lower value of $22.5 \%$ followed by the black-skinned purebred mating groups with $19.5 \%$. The white-skinned purebred mating groups recorded a negative percent variability of $-1.68 \%$, confirming that the eggs of $A$. achatina are longer than those of $A$. marginata (Tables 1 and 2). This means that improvement of this trait will be markedly affected by the environment.

The results of egg width percent variability of this study were $24.6 \%, 1.12 \%$ and-1.18 \% for BS X BS, WS X WS and BS X WS mating groups respectively (Table 2). The low percent variability values obtained in this study for the white-skinned purebred (WS X WS) and the crossbred (BS X WS) mating groups showed that there is little or no variation in egg width between the two breeds. Improvement of this trait will therefore not be affected by environmental factors.

Table 4. Percent variability among hatchling traits of $A$. marginata and A. achatina

\begin{tabular}{lrrrr}
\hline Mating group & Age (Weeks) & & $\begin{array}{c}\text { Percent Variability } \\
\text { Body Length of Hatchlings }\end{array}$ & Body Width of Hatchlings \\
\hline BS X BS & 0 & Body Weight of Hatchlings & 13.7 & 17.8 \\
& 1 & 52.6 & 13.0 & 19.0 \\
& 2 & 48.4 & 13.2 & 18.2 \\
& 3 & 43.5 & 13.0 & 16.7 \\
WS X WS & 4 & 41.1 & 14.1 & 17.7 \\
& 0 & 7.79 & 1.14 & 1.75 \\
& 1 & 0.00314 & -2.42 & 3.07 \\
& 2 & -3.09 & 6.61 & 2.67 \\
BS X WS & 3 & -1.83 & 2.17 & 3.99 \\
& 4 & 2.44 & 19.5 & -1.17 \\
& 0 & 4.11 & 21.5 & 2.54 \\
& 1 & 15.8 & 22.1 & 7.28 \\
& 2 & 21.4 & 22.3 & 8.10 \\
& 3 & 21.9 & 22.4 & 10.4 \\
\hline
\end{tabular}

$\mathrm{BS}=$ Black-skinned ectotype, WS = White-skinned ectotype.

Table 4 shows the percent variability among hatchling traits for the three mating groups. There were very high percent variability values for mean hatchling weight, from $52.6 \%$ to $41.1 \%$ (at hatch to four weeks of age respectively) for the black-skinned purebreds of the two breeds. Lower and insignificant mean hatchling weight value ranges of $7.79 \%$ to $2.44 \%$ and $4.11 \%$ to $26.7 \%$ for the white-skinned purebred and the crossbred mating groups respectively were obtained. Percent variability for mean hatchlings shell length and shell width for the three mating groups was lower, especially for the white-skinned purebred mating group. These results confirmed earlier findings that there is little or no variations in hatchlings shell length and shell width for the white-skinned purebred mating group.

The variability among the traits measured in this study revealed that the influence of genes on these different traits differ from one to another.

\subsection{Correlations among Egg and Hatchling Traits}

Tables 5, 6 and 7 showed positive and highly significant phenotypic correlations $\left(\mathrm{r}_{\mathrm{p}}\right)$ within egg traits for the two ectotypes within the two snail breeds studied. The highest correlation among egg traits in the BS X BS mating group were between egg weight and egg length in A. marginata and A. achatina $(\mathrm{r}=0.825$ and 0.830 respectively), whereas egg length and egg width had the least correlation in both breeds ( $\mathrm{r}=0.750$ for $A$. marginata and $\mathrm{r}=0.720$ for A. achatina) (Table 5). For the WS X WS mating group, egg weight and egg length had the highest correlation $(\mathrm{r}=0.835)$ for $A$. marginata while it was egg weight and egg width in $A$. achatina ( $\mathrm{r}$ $=0.850)$. The least correlation values were observed between egg length and egg width in both breeds $(\mathrm{r}=0.705$ for A. marginata and $\mathrm{r}=0.700$ for A. achatina) (Table 6). Results on Table 7 showed that for the BS X WS mating group, egg weight and egg width had the highest correlation $(\mathrm{r}=0.850)$ in $A$. marginata while it was egg weight and egg length $(\mathrm{r}=0.800)$ in A. achatina. As was the case in the BS X BS and WS X WS mating groups, the least correlation was between egg length and egg width in both A. marginata $(\mathrm{r}=0.720)$ and A. achatina $(\mathrm{r}=$ 0.760) (Table 7). The highly significant correlation among egg traits obtained in these mating groups is similar to 
the reports of Ibom (2009). The positive correlation values recorded among these egg traits could imply that the traits are influenced by the same genes in the same direction.

Table 5. Phenotypic correlation coefficient $\left(\mathrm{r}_{\mathrm{p}}\right)$ among egg traits of BS X BS mating group

\begin{tabular}{|c|c|c|c|}
\hline \multicolumn{4}{|c|}{ A. Marginata } \\
\hline & EW & ED & EL \\
\hline EW & & 0.800 & 0.825 \\
\hline ED & 0.815 & & 0.750 \\
\hline EL & 0.830 & 0.720 & \\
\hline
\end{tabular}

EW = Egg Weight, ED = Egg Width, EL = Egg Length.

Table 6. Phenotypic Correlation Coefficient $\left(\mathrm{r}_{\mathrm{p}}\right)$ among egg traits of WS X WS mating group

\begin{tabular}{cccc}
\hline & $A$. & marginata & \\
\hline & $\mathrm{EW}$ & $\mathrm{ED}$ & $\mathrm{EL}$ \\
\hline EW & 0.850 & 0.820 & 0.835 \\
ED & 0.805 & 0.700 & 0.705 \\
EL & $A$. & Achatina \\
\hline \multicolumn{4}{c}{} \\
\hline
\end{tabular}

EW $=$ Egg Weight, $\mathrm{ED}=$ Egg Width, EL = Egg Length.

Table 7. Phenotypic correlation coefficient $\left(\mathrm{r}_{\mathrm{p}}\right)$ among egg traits of BS X WS mating group

\begin{tabular}{cccc}
\hline & A. & marginata & \\
\hline & EW & ED & EL \\
\hline EW & & 0.850 & 0.810 \\
ED & 0.798 & & 0.720 \\
EL & 0.810 & 0.760 & \\
\hline \multicolumn{4}{c}{ A. } \\
\hline
\end{tabular}

$\mathrm{EW}=$ Egg Weight, $\mathrm{ED}=$ Egg Width, EL = Egg Length.

Hatchling traits of the two ectotypes of the two breeds of snails studied are presented on Tables 8,9 and 10 . For the BS X BS mating group, hatchling length correlated more closely with hatchling width $(\mathrm{r}=0.750)$ for $A$. marginata and between hatchling weight and hatchling width $(\mathrm{r}=0.800)$ for A. achatina (Table 8). The WS X WS mating group results showed that hatchling length and hatchling width were more closely correlated in $A$. marginata $(\mathrm{r}=0.725)$, while hatchling weight and hatchling length were more closely correlated $(\mathrm{r}=0.870)$ in $A$. achatina (Table 9). In the BS X WS mating group (Table 10), hatchling length and hatchling width correlated more closely in A. marginata $(\mathrm{r}=0.820)$, while hatchling weight and hatchling length correlated more closely $(\mathrm{r}$ $=0.870$ ) in A. achatina. The positive correlation values recorded among these hatchling traits could mean that the traits are influenced by the same genes in the same direction. This corroborates Ibom (2009) who reported close relationships between traits of $A$. marginata (S). Besides, this correlation could also suggest that there are direct relationships between the traits, and that selection for one trait will lead to improvement in the other trait. The results of this study agree with the view of Ehiobu and Kyado (2000) that correlation can be either high or low, positive or negative and/or no correlation at all between traits.

Table 8. Phenotypic correlation coefficient $\left(r_{p}\right)$ among hatchling traits of BS X BS

\begin{tabular}{cccc}
\hline & $A$. & Marginata & HL \\
\hline & HW & HD & 0.670 \\
HW & 0.800 & 0.605 & 0.750 \\
HD & 0.850 & 0.650 & \\
HL & A. & achatina \\
\hline \multicolumn{4}{c}{}
\end{tabular}

$\mathrm{HW}=$ Hatchling Weight, $\mathrm{HD}=$ Hatchling Width, $\mathrm{HL}=$ Hatchling Length. 
Table 9. Phenotypic correlation coefficient $\left(\mathrm{r}_{\mathrm{p}}\right)$ among hatchling traits of WS X WS

\begin{tabular}{cccc}
\hline & $A$. & marginata & HL \\
\hline & HW & HD & 0.670 \\
HW & 0.820 & 0.655 & 0.725 \\
HD & 0.870 & 0.630 & \\
HL & A. & achatina \\
\hline \multicolumn{4}{c}{}
\end{tabular}

$\mathrm{HW}=$ Hatchling Weight, $\mathrm{HD}=$ Hatchling Width, $\mathrm{HL}=$ Hatchling Length.

Table 10. Phenotypic correlation coefficient $\left(r_{p}\right)$ among hatchling traits of BS X WS

\begin{tabular}{|c|c|c|c|}
\hline & $A$. & marginata & \\
\hline & HW & HD & $\mathrm{HL}$ \\
\hline HW & & 0.690 & 0.671 \\
\hline HD & 0.815 & & 0.820 \\
\hline \multirow[t]{2}{*}{$\mathrm{HL}$} & 0.880 & 0.680 & \\
\hline & $A$. & achatina & \\
\hline
\end{tabular}

$\mathrm{HW}=$ Hatchling Weight, $\mathrm{HD}=$ Hatchling Width, $\mathrm{HL}=$ Hatchling Length.

However, positive correlation here denotes that the pairs of traits have direct relationship or at least they are controlled by the same genes in the same direction as earlier pointed out by Ibom (2009) and Okon et al. (2009b). Thus those egg and hatchling traits with strong positive correlation can be selected for improvement of the snail breeds, as selection for one trait can lead to improvement of another.

\section{Conclusion and Recommendations}

The study on reproductive efficiency of two most popular snail breeds [Archachatina marginata (S) and Achatina achatina (L)] in Nigeria indicated that at lay highly significant differences existed in mean egg weight and mean egg length between the black-skinned purebreds (BS X BS) and the black-skinned $\mathrm{x}$ white-skinned crossbreds (BS X WS), with the exception of the white-skinned purebreds (WS X WS) which recorded a nonsignificant mean egg weight at lay. Highly significant differences in mean hatchling weights and mean shell width also existed between the black-skinned purebreds (BS X BS) of A. marginata and A. achatina, revealing that the black-skinned $A$. marginata is naturally superior in size to the black-skinned A. achatina.

We therefore recommend the intensive domestication and massive production of $A$. marginata since it appears to have higher potentials to meet the animal protein supply of the populace than A. achatina.

\section{References}

Adedire, C. O., Imevbore, E. A., Eyide, E. O., \& Ayodele, W. I. (1999). Aspects of physiology and complementary roles of the microbial enzymes in the intestinal tract of giant land snail Archachatina marginata (Swainson). Journal of Technoscience, 3, 6-11.

Adeyeye, E. I. (1996). Waste yield, proximate and mineral composition of three different types of land snail found in Nigeria. International Journal of Food Science and Nutrition, 47(2), 111-116.

Ajayi, S. S., Tewe, O. O., Moriarty, C., \& Awesu, M. O. (1978). Observations on the biological and nutritive value of the African giant snail (Archachatina marginata). East African Wildlife Journal, 16, 85-95.

Akinnusi, O. (2002). Introduction to Snails and Snail Farming. Abeokuta, Nigeria. Triolas Exquisite Ventures.

Akinnusi, O. (2004). Introduction to Snails and Snail Farming. $2^{\text {nd }}$ ed. Abeokuta, Nigeria. Triolas Exquisite Ventures.

Amubode, F. O. (1994). Growth and Reproductive Performance of Two Species of African Giant Snail (Achatina achatina and Archachatina marginata). Journal of Tropical Forestry Research, 9 \& 10, 68-74.

Amusan, J. A., \& Omidiji, M. O. (1998). Edible Land Snail. A Technical Guide to Snail Farming in the Tropics. Ibadan. Variety Printers Limited.

Awesu, M. O. (1980). The biology and Management of the African Giant Land Snail (A. marginata). Master of Philosophy Thesis. University of Ibadan, Ibadan, Nigeria. 
Ehiobu, N. G., \& Kyado, J. A. (2000). Heritability, Repeatability and Genetic correlation of Swine. Proceedings of the $25^{\text {th }}$ Annual Conference of Nigerian Society for Animal Production (NSAP). March 19-22, 2000. Umudike, Nigeria. pp. 260-261.

Ejidike, B. N. (2002). Snail Rearing practices in Southern Nigeria. Proceeding of the $27^{\text {th }}$ Annual Conference of Nigerian Society for Animal Production. (NSAP). March 17-21, 2002. Akure, Nigeria. pp. 307-308.

Ibe, S. N. (1998). An Introduction to Genetics and Animal Breeding. Ikeja, Nigeria. Longman Nigeria Plc.

Ibom, L. A. (2009). Variations in reproductive and growth performance traits of white-skinned x black-skinned African giant snail hatchlings [Archachatina marginata (Swainson)] in Obubra, Nigeria. Doctor of Philosophy Thesis, Department of Animal science, University of Calabar, Calabar, Nigeria.

Ibom, L. A., Okon, B., \& Essien, A. (2008). Morphometric analysis of eggs laid by two ectotypes of snail Archachatina marginata (Swainson) raised in captivity. Global Journal of Agricultural Sciences, 7(2),119121.

Imevbore, E. A. (1990). Management Techniques in Rearing African Giant Land Snail, (Archachatina marginata). Doctor of Philosophy Thesis. University of Ibadan, Ibadan, Nigeria.

Madukwe, M. C. (2004). Multivariate Analysis for Agricultural Extension Research. In (T. A. Olowu eds.) Research Methods in Agricultural Extension. Agricultural Extension Society of Nigeria. (AESON). C/o Agricultural and Rural Management Training Institute (ARMTI). Ilorin. Pp. 206-236.

Odunaiya, O., \& Akinyemi, A. A. (2008). Performance of two snail species-Archachatina marginata $(S)$ and Achatina achatina (I) reared under the same management practices. Nigerian Journal of Animal Production, 35(2), 224-229.

Okon, B. (2008). Sow Litter Variability and Performance of Piglets from Birth to 24 weeks in Ibadan, Nigeria. Doctor of Philosophy Thesis, University of Ibadan, Ibadan, Nigeria. p. 229.

Okon, B., Ibom, L. A., \& Odido, E. E. (2011). Reproductive Performance and Egg Quality Traits of Crossbreeding between Two Strains of Snails. Archivos De Zootecnia, 60(229), 153-156. http://www.uco.es/organiza/servicio/publica/az/php/az.php

Okon, B., Ibom, L. A., Ekpo, I. A., \& Ewa, E. C. (2009a). Evaluation of Reproductive performance and some Egg Quality Parameters of Albino Snails (Archachatina marginata saturalis (Swainson). Journal of Applied Science, 12(1), 8234-8240.

Okon, B., Ibom, L. A., Williams, M. E., \& Akpakpan, I. E. (2009b). Comparative Evaluation of Reproductive Performance and some Egg Quality parameters of Black and white skinned snails. Global Journal of Agricultural Sciences, 8(1), 77-80.

Olawoyin, O. O., \& Ogogo, A. U. (2006). Prediction of Optimum Stocking Density in Growing African Giant Land Snails. Tropical Journal of Animal Science, 9(2), 75-84.

Omole, A. J. (1998). The utilization of different energy supplements on performance characteristics of grower Edible giant land snail (Archachatina marginata). Master of Science Thesis. Animal Science Department, University of Ibadan, Ibadan, Nigeria.

Omole, A. J., \& Kehinde, A. S. (2005). Backyard snail farming at a glance. Back to Agricultural series (1). Ibadan. Technovisor Agricultural Publications.

Omole, A. J., Taiwo, A. A., \& Amusan, J. A. (2007). Technical Guide/Bulletin. Practical snail farming. Ibadan, Nigeria. Institute of Agricultural Research and Training, Moor Plantation.

Plummer, J. M. (1975). Observations on the reproduction, growth and longevity of a laboratory colony of Archachatina (Calachatina) marginata. Proceedings of the Malacological Society. London. 141, 395-413.

SAS. (1995). Statistical Analysis System. Institute Inc., Users' Guide Statistics Institute Inc., Version 6 ed. Statistical Analysis Systems Carry, North Carolina, USA. 